\title{
Relations Without Polyadic Properties: Albert the Great On the Nature and Ontological Status of Relations
}

\author{
Jeffrey E. Brower (Purdue University)
}

I think it would be fair to say that, until about 1900, philosophers were generally reluctant to admit the existence of what are nowadays called polyadic properties (for our purposes we may think of a polyadic property as a property whose instances can belong to two or more subjects at once). ${ }^{1}$ It is important to recognize, however, that this reluctance on the part of pre-twentieth-century philosophers did not prevent them from theorizing about relations. On the contrary, philosophers from the ancient through the modern period have had much to say about both the nature and the ontological status of relations. In this paper I examine the views of one such philosopher, namely, Albert the Great (d. 1280).

Albert the Great is perhaps best known today as the teacher of Thomas Aquinas, but during his own lifetime he was highly esteemed as a philosopher and theologian (indeed, if the testimony of Roger Bacon is to be trusted, his views were often accorded as much weight as those of Aristotle, Avicenna, and Averroes). Albert was among the first scholastic thinkers to have access to the Aristotelian corpus in its entirety, and he devoted his scholarly career to making Aristotle's thought intelligible to philosophers in the Latin West. He was a prolific writer and drew on a broad range of sources (Arabic, Greek, and Byzantine). His corpus is an encyclopedic body of work covering all aspects of medieval learning, including philosophy, theology, and the natural sciences. ${ }^{2}$

As we shall see, Albert's discussion of relations is of particular philosophical interest. Despite the fact that he denies the existence of polyadic properties, he 
nonetheless maintains that relations constitute a distinct category of being. That is to say, relations are not just monadic properties, according to Albert, they are a sui generis type of monadic property. In the course of examining his theory, I intend to make clear not only how Albert can consistently maintain such a position, but also the reasons why he (or anyone like him) might be inclined to do so. In the process, moreover, I uncover an interesting dialectical position whose merits have been entirely overlooked in contemporary discussions of relations.

In addition to being philosophically interesting, Albert's discussion of relations is also historically important, shedding light on the development of medieval theories of relations generally. Because of its systematic nature, Albert's discussion illuminates the main types of theory one can adopt with respect to the nature and ontological status of relations, and enables us to identify the sorts of considerations that led particular medieval philosophers to prefer one type of theory over another. Moreover, because Albert's discussion contains an extensive treatment of anti-realism about relations, it sheds some light on a position which, though certainly a minority view in the Latin West, appears to have had a significant following in the Arabic-speaking world.

Albert discusses relations in a number of different contexts, many of which are theological in nature. In what follows, I focus only on those contexts in which Albert develops (as opposed to refines or extends) the general type of theory to which he is committed. $^{3}$ The most important texts in this regard are Albert's philosophical commentaries on Aristotle's $\underline{\text { Categories }}$ and $\underline{\text { Metaphysics. }} .{ }^{4}$ Although both of these works follow the subject matter and arrangement of Aristotle's texts, neither is a commentary or paraphrase in the strict sense. Indeed, as we shall see, in each case these Aristotelian texts provide Albert with an occasion to develop his own (broadly Aristotelian) views. 


\section{BACKGROUND}

Aristotle's Categories introduced medieval philosophers to an exhaustive division of "things said without combination". ${ }^{5}$ Although Aristotle divides these things into ten categories or classes, he discusses only the first four in any detail-namely, substance, quantity, quality, and relation.

In Categories 7 Aristotle singles out the category of relation for independent consideration. He assumes that its members are a certain type of accident, and hence that the nature of relations must be explained, at least in part, by their inhering in particular substances. This assumption may help to explain why, unlike contemporary philosophers, who habitually speak of relations as holding between two or more individuals, Aristotle prefers to say that relations inhere in one thing and somehow point toward (pros) another. Indeed, Aristotle's preferred name for this category just is toward something (pros ti).

By Albert's time it was customary for medieval philosophers to refer to the category of relations using not only Aristotle's term, "toward something" (or ad aliquid, the verbatim Latin equivalent of pros $\underline{\text { ti) }}$, but also the terms "relative" (relativum) and "relation" ( paying much attention to their various senses. ${ }^{6}$ Although Albert himself often follows this common medieval practice, we shall eventually see that there comes a point in each of his commentaries when he wants to maintain, not only that these terms differ in sense, but that their different senses are important for understanding the nature of relations.

Let us turn now to Albert's characterization of relations. Following medieval logical tradition, Albert refers to the first three Aristotelian categories-namely, substance, quantity, and quality —as absolute categories (absoluta), and attempts to distinguish relations from the members of these absolute categories by appealing to 
broadly logical considerations. A relation, he says, is what is signified by a certain type of predicate, one which he and other medieval philosophers call a "relative term" (ad aliquid or relativum).$^{7}$ Roughly speaking, a relative term is a predicate whose true predication requires a comparison of the subject of predication to something else. For obvious reasons, Albert gives "taller" (ㅌius) as a paradigm example of this sort of term. For when we assert of an individual, say Simmias, that he is taller - that is, when we predicate the term "taller" of him—we necessarily do so in comparison to something else. We don't merely say that Simmias is taller; we say that he is taller than Socrates, or Theatetus, or the average man. If we borrow on Albert's behalf the notation of first-order logic, we can make his characterization more precise by saying that a term $\underline{F}$ is relative just in case a statement of the form "Fx" is more perspicuously represented by a statement of the form "Fxy". (We can say that a term $\underline{F}$ is absolute, by contrast, just in case it is not relative. $)^{8}$

According to Albert, therefore, relations are the entities signified by relative terms (such as "taller") - that is to say, they are the significata of what we would nowadays call relational predicates. ${ }^{9}$ It is important to notice that this characterization of relations does not, by itself, commit Albert to any substantive view about the nature or ontological status of relations. For it is still an open question at this point what the $\underline{\text { significata }}$ of relational predicates are, and hence what sorts of entities, if any, qualify as relations in Albert's sense.

As it turns out, Albert thinks there are only two views that one can take with regard to the nature and ontological status of relations. One can either be a realist, and say that the significata of at least some of our relational predicates are (non-linguistic) entities existing in extramental reality, or one can be a conceptualist, and say that they are entities existing only in the mind. Now initially it might seem odd that Albert thinks of 
these as the only two alternatives. After all, couldn't there be a form of anti-realism other than conceptualism - say, nominalism, where this is understood either as the view that relational predicates are not significant, or else as the view that their significata are mere words or linguistic expressions (nomina)? The correct answer for Albert, I think, is "no". Albert assumes that relational predicates are meaningful, and on his semantic theory, words are meaningful in virtue of signifying, or being subordinated to, particular concepts. ${ }^{10}$ But this already insures that relations exist at least in the mind (as concepts). For if relational predicates are meaningful, and meaningful predicates signify concepts, then relational predicates signify concepts. But these concepts must themselves be relations, since as we have seen, Albert thinks relations just are the significata of relational predicates. Initially, therefore, the important question for Albert is not whether relations exist, but whether they exist only in the mind. And in order to answer this question he thinks we must decide whether anything in extramental reality corresponds to any of our relational concepts. For according to him, meaningful terms signify not only concepts, but whatever (if anything) is represented by these concepts in extramental reality.

In order to bring out what is important in Albert's conception of the debate between realists and conceptualists, we may characterize their opposing views as follows:

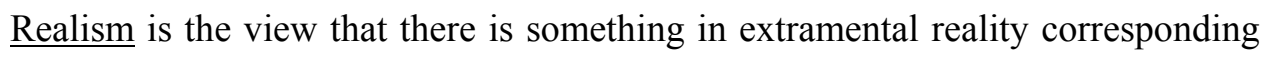
to at least some of our relational concepts.

Conceptualism is the view that there isn't anything in extramental reality corresponding to any of our relational concepts. ${ }^{11}$ 
Keeping in mind that these are, as Albert sees it, the only genuine alternatives one can take with respect to the nature and ontological status of relations, let us turn to his own view.

\section{REALISM ABOUT RELATIONS}

In both of the commentaries I mentioned earlier - the Categories commentary and the commentary on the Metaphysics-Albert makes it clear that he accepts a form of realism about relations. What seems to be driving his realism, moreover, is a particular conception of the Aristotelian categories. According to Albert, the ten categories do not classify mere concepts or beings of reason (entia rationis); they classify things existing in extramental reality ( $\underline{\text { res })}$. Since relation is one of these categories, he thinks that there must be some extramental beings that comprise it—beings which in turn correspond to our relational concepts.

Albert begins his discussions of relations in both commentaries by taking up several anti-realist objections. In his commentary on the Categories, he considers six objections, most of which purport to show that relations are mere beings of reason-that is, that there are relational concepts but nothing in extramental reality corresponding to them. Although Albert claims that "the ancients, and nearly all philosophers besides Plato and Aristotle, have been moved to [reject realism] on the basis of these and other such arguments", his own commitment to realism is unwavering. "We agree" says Albert "with Plato and Aristotle: we maintain that toward something is a most general genus, and one of the most general genera of accident." ${ }^{, 12}$

When we turn to the commentary on the Metaphysics, we also find Albert addressing several anti-realist objections. In this work, however, he construes the conclusion of the objections more broadly, so that what they purport to show is merely 
that relations do not exist in extramental reality (without explicitly drawing the conclusion that relations therefore exist only in the mind). Once again, however, Albert's own position is clear. "In response to this"- that is, in response to the sort of antirealism just advanced_-"we say that in fact (and in accordance with the wisdom of the Peripatetics) relation has being." 13 It is clear from the context, moreover, that he means "relation has extramental being".

It is tempting for us, in the early twenty-first century, to suppose that realism about relations implies the existence of polyadic properties. Albert does not himself, however, think that realism has this implication. According to him, relations comprise one of the accidental categories of being. And like so many Aristotelians over the centuries, Albert conceives of accidents in such a way that their particular instances - the so-called particular accidents — can belong to only one subject at a time. ${ }^{14}$ But if relations are accidents, and accidents are properties whose instances can belong to only one subject at a time, then relations would appear to comprise a category of monadic, as opposed to polyadic, properties.

None of this goes to show, however, that Albert lacked the concept of a polyadic property, or even that he failed to consider the possibility of its instantiation. In fact, near the end of his discussion of relations in the Categories commentary, Albert appears to consider and then explicitly to reject the existence of polyadic properties. In this passage, he is considering whether converse relations, such as fatherhood and sonship, are numerically distinct entities or just one entity standing between two (or more) related substances. ${ }^{15}$ In support of the latter view, Albert imagines someone offering the following analogy: 
It seems that sonship and fatherhood differ only as regards their termini, just as the road which runs from Thebes to Athens is the same as the road which runs from Athens to Thebes, although there is a difference in termini. ${ }^{16}$

Albert's response to this analogy is telling. Although he admits that a relation is similar to a road in a certain respect, he denies that there is anything in extramental reality extending between the relata of a relation:

As for what was objected about its being the same road which runs from Thebes to Athens, and in the reverse direction, it must be said that, except as regards their termini, this case is not altogether similar [to the one involving converse relations]. [For in the case of a father and son] there is nothing extended between them. $^{17}$

This passage would seem to contain a straightforward rejection of polyadic properties. According to Albert, there is nothing extended between related individuals, such as a father and his son. If we consider a relational proposition, such as 'Socrates is son of Sophroniscus', and analyze it into a pair of proper names and the relational concept 'is son of', we can put Albert's point by saying that there is nothing in extramental reality corresponding to - or better, nothing there isomorphic with — the concept involved in this proposition. As the context makes clear, however, Albert intends the point to apply not only to fatherhood and sonship, but to converse relations generally.

But even if it is clear that Albert rejects the existence of polyadic properties, we need to be careful how we understand his rejection. We should not, for example, merely say that on Albert's view there is nothing in extramental reality corresponding to any of our relational concepts. For as we have seen, Albert is a realist about relations, and realism as we defined it earlier requires that something in extramental reality corresponds to at least some of our relational concepts. If we are to understand his rejection of 
polyadic properties, therefore, we must interpret it as the claim that, although there is something in extramental reality grounding at least some of our relational concepts, this extramental ground is not polyadic in nature.

Albert recognizes the need for caution in this regard. This is especially clear in his Categories commentary, where he suggests that the denial of polyadic properties forms the basis of the strongest (or at least most persuasive) anti-realist objection to his own view. In the next section, I want to consider Albert's treatment of this anti-realist objection in some detail, for as we shall see, it not only serves to clarify his own view, but also to reveal the inadequacy of the standard logical objections to monadic theories of relations.

\section{REALISM WITHOUT POLYADIC PROPERTIES}

In his Categories commentary, Albert claims that the strongest objection to any form of realism about relations derives from the work of Avicenna (d. 1037) and Alfarabi (d. 950). Having already considered several other anti-realist objections, whose ancestry he traces to ancient Greek philosophers such as Zeno of Citium (d. 262 BC), ${ }^{18}$ Albert introduces the sixth and final objection as follows:

Some more recent philosophers, such as Avicenna and Alfarabi, have a stronger objection. They say that no form that is a being ( $\underline{\text { ens }}$ ) belongs to a thing (res) unless it is absolute as far as the being (esse) that it has in itself is concerned-as is clear from looking at particular cases of what is hot, cold, white, black, and all other things. And yet the comparison of things to one another, which comes about in accordance with forms that are in these things, comes about by an act of reason which says [e.g.] that things lacking a single quality are dissimilar and things having a single quality are similar. But, then, the form that is in the things 
which are toward something, which is the basis of the comparison, is not a reality (res) but a concept ( $\underline{\text { ratio }}$ ) - or so it seems, since there is nothing outside the soul of the person who compares the one thing to the other. ${ }^{19}$

Although Albert traces this anti-realist objection to Avicenna and Alfarabi, it's unclear from the text whether he thinks these philosophers actually reject realism, or merely supply the most powerful objection to it. ${ }^{20}$ Since it seems clear to me, at least in the case of Avicenna, that he accepts a form of realism about relations, I shall hereafter avoid speaking in ways that would suggest that either Avicenna or Alfarabi endorse the objection. $^{21}$

The purpose of the sixth objection is to show that relations are not beings in any ontologically significant sense- they exist as mere concepts or beings of reason. Indeed, when Albert summarizes the whole objection a few lines later he states its conclusion in just this way: "Toward something [or relation] is not a [type of] being established in extramental reality, but a being of reason ( $\underline{\text { ens }} \underline{\text { rationis)}}$." ${ }^{, 22}$ It is important to notice, however, that in the actual statement of the objection Albert speaks, not of "relation" or "toward something", but of "comparison" (omparatio) and "the form which is the basis of the comparison" (comparationis forma). This is way of speaking is characteristic of Albert's treatment of anti-realism in the Categories commentary, which habitually employs the term "comparison" as a near synonym for "relation". ${ }^{23}$ This choice of terminology might seem to beg the question in favor of conceptualism, or at least to make the conclusion of the objectors' argument trivial (namely, that comparisons exist only in the mind). But this is just an appearance. As we shall see, Albert is perfectly willing to speak of comparisons themselves existing outside the mind. ${ }^{24}$

If we turn now to the structure of the sixth objection, we can see that it begins with an appeal to ordinary sensory experience. According to the objectors, we are not 
presented in sense experience with anything but individuals and their so-called absolute forms - that is, substances and their quantities and qualities. "This is clear" they say "from looking at particular cases of what is hot, cold, white, black, and all other things." The point that is being made here is, I think, fairly intuitive. Suppose the following are set before you: a cup of hot, black coffee and a container of cold, white cream. Clearly you can, if you wish, single out the coffee and attend to some of its properties, such as its specific color and temperature. The same is true of the cream: you can see its whiteness and feel its coldness. But what about the relations (such as similarity and dissimilarity) that hold between the coffee and cream? Can you plausibly be said to perceive them by virtue of your senses? Presumably such relations cannot literally be said to exist between the coffee and cream — that is, in the place bounded by their bodies. But, then, where can they be said to exist, and by what mode of consciousness are they given $?^{25}$

On the basis of this intuitive appeal to experience, the objectors think that they are entitled to draw the following conclusion (see lines 2-3 of their objection quoted above):

No form that is a being belongs to a thing unless it is absolute as far as the being that it has in itself is concerned.

Here the objectors attempt to identify what they think is the only type of form that can be included among the objective properties of individuals. As the objection proceeds, it becomes clearer that they are using the term "being" ( $\underline{\text { ens })}$ ) and its cognates to contrast things existing in extramental reality ( $\underline{\text { res })}$ with things that exist only in the mind, namely, concepts ( $\underline{\text { rationes}})$. Thus, when they speak here of "forms that are beings", this should be interpreted to mean forms that exist outside the mind. Moreover, when they say that such forms belong to a thing only if their being is "absolute", this implies that all such forms are monadic or characterize their subjects intrinsically. What the objectors intend 
their appeal to experience to show, therefore, is that only monadic forms can be included among the objective properties of individuals. And of course this is just another way of saying that there are no polyadic forms or properties in extramental reality.

Having rejected the existence of real polyadic forms or properties, the objectors are now in a position to deny the existence of relations in extramental reality. Before drawing this conclusion, however, they make explicit an assumption that is perhaps already intuitive (see lines 8-11):

The form [...] which is the basis of the comparison is not a reality but a concept - or so it seems, since there is nothing outside the soul of the person who compares the one thing to the other.

The point, of course, is that if there are no polyadic forms or properties outside the mind, there is nothing in extramental reality corresponding to our relational concepts.

Bringing all of these points together, we may reconstruct the sixth objection as follows:

(1) There are no polyadic forms or properties in extramental reality. [Appeal to experience.]

(2) If there are no polyadic forms or properties in extramental reality, then there isn't anything in extramental reality corresponding to our relational concepts. [Assumption]

(3) But if there isn't anything in extramental reality corresponding to our relational concepts, then relations exist only as concepts in the mind (i.e., realism is false). [Implicit Assumption]

$\therefore \quad$ (4) Relations exist only as concepts in the mind (i.e., realism is false). ${ }^{26}$

It is not surprising that Albert regards this objection as the strongest of all the anti-realist objections he considers in his Categories commentary, for as we have seen, he 
is committed to its first premise. Despite his sympathy for the starting point of the objection, however, and despite the intuitive plausibility of its other premises, Albert ultimately regards the objection as fallacious. In order to see why, let's turn to his response:

In reply to what the more recent philosophers objected, it must be said that, evidently, one can understand comparison in two ways: [i] in accordance with aptitude, and [ii] in accordance with actuality. Now in accordance with aptitude, a comparison exists in things [...] But in accordance with actuality, a comparison exists in the mind or soul of the one comparing. Such an actuality does not require that [the comparison] exist in the things compared as anything other than an aptitude. For this reason, a comparison exists in things in accordance with aptitude but in the mind in accordance with perfection. ${ }^{27}$

Initially it might not seem clear how this reply is relevant to the objectors' argument. Indeed, insofar as it allows that relations (or comparisons) exist 'in actuality' only in the mind, it might appear just to concede the objectors' main point. It is important to emphasize, therefore, that Albert thinks there is a genuine sense, albeit a diminished one, in which relations exist in extramental reality. Thus, despite the fact that he says relations exist in actuality only in the mind, he nonetheless insists that this is compatible with saying that they exist 'in aptitude' outside the mind. Evidently, therefore, even if there are no extramental polyadic forms or properties, Albert thinks the anti-realist conclusion his objectors' draw-namely, that relations exist only as concepts in the mind-is too strong.

The important question, of course, is what it means to say that relations exist outside the mind merely in accordance with aptitude. On the sort of picture that Albert has in mind (roughly that given by Aristotle in the Physics), an aptitude is a power or a 
potentiality for a specific type of activity. In the case of relations, the relevant power is the power for being compared or related in the mind of some cognizer. Thus, when Albert says that relations exist in things merely in aptitude, this just appears to mean that there exist some properties of things in virtue of which they are apt to be compared. Thus, to return to my earlier example, coffee is similar to cream in some respect because it has properties which enable us to form a (true) judgment or comparison in which the concept of similarity is applied to the coffee and cream.

In order to bring out the significance of Albert's reply, it may be useful to consider an analogy that has come to be used in a variety of contemporary contexts, namely, the analogy to so-called secondary qualities (colors, tastes, sounds, warmth and coldness, etc.). Since the seventeenth century, philosophers and scientists have been developing a conception of the world that might seem to allow no place among the objective properties of bodies for qualities such as colors, tastes, and sounds. The objective properties of bodies, we are told, include only such qualities as extension, shape, and motion. This is not, of course, to deny that we have ideas of colors, tastes, and sounds, but only to deny that anything in the external environment is at all like them.

Now it is easy to imagine how someone, on first being presented with this scientific world-view, might draw the conclusion that colors, tastes, and sounds exist only in the mind-meaning by this that words like "red", "juicy", and "sweet" apply, not to bodies such as apples or strawberries, but only to our sensations, ideas, or experiences of them. But as philosophers since the time of John Locke have been reminding us, inferences of this sort are fallacious. Even if nothing in the external environment resembles our ideas of redness or sweetness, it doesn't follow that the ideas themselves have no genuine application to things in that environment. After all, such ideas may apply to things solely in virtue of qualities such as extension, and shape, and motion. 
In order to guard against fallacious inferences of the sort just mentioned, Locke explicitly distinguishes two different types of quality. All qualities, he suggests, are powers to produce ideas or sensations in us. Some qualities, however, are in some sense similar (or isomorphic) to the ideas or sensations that they produce, whereas others are not. The former he calls primary or original qualities, since "their patterns do really exist in the bodies themselves", whereas the latter (or a species of the latter) ${ }^{28}$ he calls secondary qualities, since they no more resemble something existing in a body than "the names that stand for them are the likenesses of our ideas". Again, to emphasize their distinction, Locke describes the so-called secondary qualities as "nothing in objects themselves but powers to produce various sensations in us by their primary qualities". ${ }^{29}$

Now when Albert describes relations as mere powers or aptitudes, he seems to be guarding against a similar sort of mistake. Thus, when he describes extramental relations as mere powers or aptitudes, he is not attempting to provide a substantive characterization of their nature, but to indicate something about their relationship to certain concepts in the mind. According to the tradition that Albert and his objectors inherit from Aristotle, there are no extramental polyadic forms or properties, and hence nothing in extramental reality like our relational concepts (at least in respect of their polyadicity). But, as Albert recognizes, this does not imply that there are no extramental relations. For there can be something in extramental reality grounding a relational concept even if this extramental ground is not isomorphic to that concept.

If we return to the sixth objection, or to my earlier reconstruction of it, we can see that Albert's reply calls our attention to an equivocation. When the objectors commit themselves to saying that "there isn't anything in extramental reality corresponding to our relational concepts" - as they do in premises (2) and (3) of their argument - they might be interpreted to mean either of two things: 
(A) There isn't anything in extramental reality isomorphic to our relational concepts.

(B) There isn't anything in extramental reality grounding the applicability of our relational concepts.

Once this ambiguity is made explicit, however, we can see that the argument rests on an equivocation. If we interpret it along the lines of (A), the second premise is true, but the third is false - or at least there is no reason to accept it. Just because there's nothing isomorphic to our relational concepts, it doesn't follow that there's nothing grounding their applicability. If, on the other hand, we interpret the argument along the lines of (B), the third premise is true, but the second is false or unmotivated. Just because there are no extramental polyadic properties, it doesn't follow that there's nothing grounding the applicability of our relational concepts. What this shows, of course, is that there is no uniform interpretation of the premises that yields a sound argument.

In addition to locating a fallacy in his objectors' reasoning, Albert's reply to the sixth objection also helps to clarify his own theory of relations. Like his objectors, Albert accepts that relational concepts are polyadic and that there is nothing in extramental reality isomorphic to these concepts. But unlike them, he does not infer that relations exist only in the mind. For, as he recognizes, even if there are no real polyadic forms or properties, relations can still exist outside the mind as powers or aptitudes. Of course, these powers or aptitudes will have to be monadic, but that's part of his reason for calling them mere powers or aptitudes. On Albert's view, therefore, there is something in extramental reality grounding the applicability of our relational concepts, it's just not polyadic in nature. Or to put the point in a slightly different way, there is something in extramental reality that corresponds to our concepts of relations, but only in the weak 
sense of "correspondence". Hereafter I shall refer to this sort of view as realism without polyadic properties.

On the basis of the analogy I drew to certain discussions in early modern philosophy, one might be tempted to describe Albert's view by saying that relations are secondary qualities. This way of describing his view, however, seems to me potentially misleading. For when a philosopher such as Locke characterizes, say, redness as a secondary quality, he intends this characterization to be understood in purely causal terms. Thus, according to Locke, redness is a power to produce a certain type of sensory impression or idea. This is not, however, what Albert has in mind when he characterizes relations (or comparisons) as mere powers or aptitudes. Relations are not, according to him, powers to cause or produce any type of sensation or idea, or even any type of judgment. On the contrary, relations are, for him, the properties or forms in virtue of which two (or more) things are comparable - that is, apt to be truly compared.

Given the subtlety of Albert's view, it is no surprise that some of his predecessors and near contemporaries should have overlooked its possibility. Albert himself makes this point as he concludes his treatment of the sixth objection. Thus, having indicated that relations can exist outside the mind as mere powers or aptitudes, he goes on to say:

This fact about the category [of relation] deceives many people [...] We certainly should concede that this [category of] accident has less being than [that had by] any absolute [category]. It does not follow, however, that this category lacks being altogether. Nor does it follow that, insofar as it has accidental being, it fails to introduce a mode of predication ( $\underline{\text { modum }}$ praedicabilium $)^{30}$ which is distinct and separate from the other accidental [modes of] predication. ${ }^{31}$ 
Albert's predecessors and near contemporaries are not the only ones to have overlooked the possibility of a theory such as his. In the next section I shall briefly indicate the extent to which this type of theory continues to be overlooked even by contemporary philosophers.

\section{A STANDARD LOGICAL OBJECTION}

In the twentieth century, the main objection to monadic theories of relations has come from logicians and philosophers of language, and is derived from the nature of relational judgments or propositions. Relational propositions, we are told, or a certain subset of them (specifically those containing asymmetrical relational concepts) cannot be reduced to propositions of any other type. The classic defense of this claim was given by Bertrand Russell in the Principles of Mathematics, but variations on it have been repeated ever since. Some philosophers, such as Russell himself, insist that relational propositions are irreducible in meaning. ${ }^{32}$ Others, such as Julius Weinberg and Reinhart Grossmann, emphasize the uniqueness of their logical form. ${ }^{33}$ Both parties agree, however, that the irreducibility of relational propositions entails the existence of real polyadic properties or relations.

Now as we have seen, there is nothing in Albert's treatment of the sixth objection to suggest that he denies the irreducibility of relational concepts or judgments. Indeed, his description of relations as mere powers or aptitudes appears to be calculated to preserve this feature of them. Obviously, Albert did not have access to the results of twentieth-century logic. Nonetheless, in the thirteenth century he could say that the category of relations introduces "a mode of predication which is distinct and separate from the other accidental [modes of] predication". 
In response to variations on this standard logical objection, therefore, it must be said that their main premise - the premise that relational judgments or propositions are irreducible - is perfectly consistent with the type of theory that Albert develops. But then what should we say about the inference involved in this sort of objection? Russell, Weinberg, and Grossmann appear to think that if relational judgments are irreducible, that can only be because the facts that make them true contain an irreducibly relational or polyadic component. But why suppose this is true? Evidently, they are guilty of the same mistake as Albert's objectors.

Consider the following three propositions:

(a) There are no real polyadic properties.

(b) Relational judgments are irreducible, and

(c) Relational concepts have an objective ground in reality.

As we have seen, Albert's objectors think that these propositions form an inconsistent triad. Because they are convinced of (a) on the basis of empirical considerations, and because they accept the truth of (b), they reject (c) in favor of some form of conceptualism. Like the objectors, Russell, Weinberg, and Grossmann appear to think that (a)-(c) form an inconsistent triad. Unlike the objectors, however, they are convinced of (b) and (c), and hence reject (a) in favor of polyadic properties.

What Albert rightly points out, however, is that these claims are not inconsistent. Of course, if we make the further assumption that

(d) Relational concepts have an objective ground in reality only if they have something in reality isomorphic to them,

then we will have an inconsistent set, since (a)-(d) form an inconsistent tetrad. But, as Albert himself reminds us, assumption (d) is false — or at least not obviously true. There is no reason in principle why the correspondence between concepts and properties must 
be a matter of isomorphism, and as we have seen in the case of secondary qualities, this assumption seems highly implausible.

In addition to helping us identify the fallacy involved in the standard logical objection to reductionism about relations, Albert also helps us to see why it is so often committed. The inference from claims about the irreducibility of relational propositions to the existence of polyadic properties ultimately depends on the assumption stated at (d). And even if this assumption is false, it has a strong intuitive appeal. After all, a natural way to think of the relationship between concepts and their objects, propositions and the facts that make them true, is on the analogy of pictures and the scenes they depict. Just as pictures resemble what they are pictures of, and their parts correspond to the parts of the scenes they depict, so too, we are inclined to think, propositions and concepts relate to facts and their constituents.

\section{REDUCTIVE VS. NON-REDUCTIVE REALISM}

We have now identified the general type of realism to which Albert is committed. There is, however, a further issue that still needs to be resolved. What, according to Albert, is the precise nature and ontological status of the properties which ground the applicability of our relational concepts?

The most obvious thing to be said about these properties is that they must be monadic. For as we have seen, they are not isomorphic to our relational concepts precisely because they are not polyadic in nature. Now on the simplest, or most ontologically parsimonious form of such realism, these properties would just be identified with what we might call ordinary monadic properties - those monadic properties which fall under the other categories of accident. This sort of view was, in fact, held by a

number of philosophers during the Middle Ages, including Peter Abelard (d. 1142). ${ }^{34}$ 
According to Abelard, if Simmias is taller than Socrates, what grounds the applicability of the relational concept, 'is taller than', to these individuals is nothing other than the possession by them of their particular heights, which fall under the category of quantity. Again, according to Abelard, if Socrates is son of Sophroniscus, what grounds the applicability of the relational concept, 'is son of', to them is nothing other than the possession by Socrates of a particular passion and the possession by Sophroniscus of a particular action (leaving aside, for the moment, questions about the nature of actions and passions). For the sake of convenience in what follows, I will refer this sort of view as reductive realism (without polyadic properties). ${ }^{35}$

We might expect reductive realism to appeal to anyone committed to realism without polyadic properties. After all, failure to reduce relations to ordinary monadic properties would seem to make them mysterious. If relations are monadic properties, but not ordinary monadic properties, then what are they? The position of the reductive realist, by contrast, is perfectly intelligible. According to it, Simmias's being taller than Socrates will be nothing other than a pair of heights - in this case, say, Simmias's being six-feet-tall and Socrates's being five-feet-ten-inches-tall. Alternatively, the reductive realist might identify this relation with just Simmias's height in certain circumstances, including the circumstance that Socrates is five-feet-ten. ${ }^{36}$

Albert's talk of relations as powers or aptitudes would seem to fit well with the second of these two alternative forms of reductive realism. For when Albert says that a relation is a mere power or aptitude he just means that a relation is that form or property in virtue of which one thing is comparable to another. As we have just seen, however, Simmias's height is plausibly regarded as that in virtue of which he is comparable to Socrates in the relevant respect. Again, if we reflect on the analogy to secondary qualities, which is suggested by Albert's talk of relations as powers, this might also lead 
us to suppose that Albert accepts a form of reductive realism. Just as secondary qualities are often thought to be nothing ontologically over and above the more scientifically acceptable primary qualities, so too, we might suppose, Albert regards relational powers as nothing over and above ordinary monadic properties of individuals.

As it turns out, however, Albert explicitly rejects any form of reductive realism. According to him, the category of relation is not just a category of being, but a distinct or irreducible category of being. Albert's commitment to this conception of relations emerges most clearly in his commentary on the Metaphysics, where he begins his discussion of the category by saying:

It is difficult for us to speak about [the category of] toward something or relation, because it has a nature and being altogether different from the genera of being which have been considered so far [namely, substance, quantity, and quality]. ${ }^{37}$ Again, a little further on he says:

[Relation] has a mode of being different from the other genera that have been introduced so far. This is because the other genera express being which is absolute, and so their essences are composed from their own principles, quite apart from the principles of the subjects in which they inhere (consider, for example, quality and quantity). But this genus does not have that sort of entitative standing ( $\underline{\text { habet }} \underline{\text { entitatem }} \underline{\text { aliquam }} \underline{\text { talem}}$ ). On the contrary, the subject's outward-looking-ness ( $\underline{\text { respectus }}$ ) itself gives entitative standing to this genus. $^{38}$

In this second passage, Albert not only distinguishes the category of relations from the other accidental categories, but provides his grounds for doing so. Relations, he says, have a distinct sort of nature or essence. Unlike the members of the absolute categories, which characterize their subjects only intrinsically, relations have a nature that is 
outward-looking. Indeed, in the second of the two passages, Albert just identifies relations with this outward-looking-ness (respectus) ${ }^{39}$

It is worth noting that in the Metaphysics commentary, where Albert is especially concerned to establish the irreducibility of this category, he begins to speak of relations as existing in actuality, whereas as in the Categories commentary he had spoken of them exclusively as mere powers or potentialities. ${ }^{40}$ This difference in speech, however, seems to me to result, not from any change in doctrine, but merely from a change in emphasis. In the Categories commentary, where Albert's primary concern was to establish a form of realism without polyadic properties, it made sense for him to speak of relations as powers or aptitudes, since this way of speaking clarifies the sense in which relations are (and are not) monadic properties. But in the Metaphysics commentary, where Albert is trying to say something informative about the nature of relations (namely, what type of monadic properties they are), this way of speaking could be misleading. For it might suggest that relations have merely potential being, whereas in fact his view is that relations are a sui generis type of actuality.

What Albert's theory of relations appears to come to, therefore, is this: there are monadic properties grounding the applicability of our relational concepts, but they are not reducible to any of the so-called ordinary monadic properties. They are, as I have said, sui generis. In order to distinguish Albert's theory from the type of realism that I attributed to Abelard, we might describe it as a form of non-reductive realism (without polyadic properties).

Now it is important to emphasize that, on Albert's theory, ordinary monadic properties are relevant to the existence of relations, even if relations cannot be identified with them. Thus, if Simmias is taller than Socrates, Simmias's and Socrates's heights will provide the foundations for this relation (as well as its converse). Likewise, 
Socrates's being son of Sophroniscus (and Sophroniscus's being father of Socrates) will be founded on an action and a passion. What divides Albert from reductive realists such as Abelard, therefore, is not the issue of whether ordinary monadic properties provide foundations for relations, but rather the issue of whether (as later the medievals would put it) relations are identical with their foundations. We might put all of this in another idiom by saying that, although Albert agrees with Abelard that relations supervene on the exemplification of certain ordinary monadic properties, he disagrees with him on the question whether relations are anything additional to that on which they supervene.

\section{RELATION AS SENSE (OR DIRECTION)}

We now come to the most difficult issue to resolve in Albert's theory of relations. As we have seen, Albert is committed to the existence of a sui generis type of monadic property, the members of which ground the applicability of our relational concepts. But now we must ask: How exactly are we supposed to conceive of these properties? Albert hints at one answer to this question in his Metaphysics commentary, where he repeatedly invokes a visual metaphor to describe the nature of relations. A

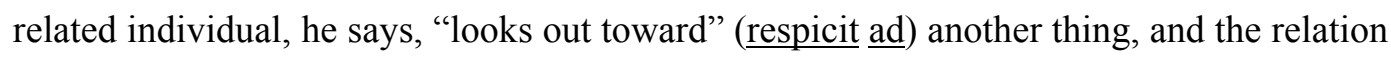
just is the individual's "outward-looking-ness" (respectus). But this just re-introduces the initial difficulty in another way. For now the question arises: How are we to understand this 'outward-looking-ness', and what does it amount to ontologically?

I suspect that the reason we find it so difficult to understand the nature of Albert's sui generis relational properties is that we have no clear understanding of the theoretical role or function they are supposed to play in his theory. We can understand why a reductive realist such as Abelard would want to say that Simmias's being taller than Socrates is nothing ontologically over and above Simmias, Socrates, and their 
respective heights. For the possession of these heights by Simmias and Socrates seems to necessitate their relation (there are no possible worlds in which, say, Simmias is six-feettall and Socrates is five-feet-ten, and yet in which Simmias fails to be taller than Socrates). But then what work is left to be done by Albert's sui generis relational properties? If one is going to reject the existence of polyadic properties, why not just go all the way and identify relations with ordinary monadic properties, which provide their foundation or supervenience base?

I think that we begin to see how Albert would respond to this question if we attend to some of his purely terminological remarks. At the outset of this paper I mentioned that Albert uses three different terms to signify relations-namely, "toward something" (ad aliquid), "relative" (relativum), and "relation" (relatio) - and that, like other medieval philosophers, he often alternates between them, as if there were no differences in their senses or meanings. I also mentioned, however, that there comes a point in each of his commentaries when he wants to maintain, not only that these terms differ with regard to their senses or meaning, but that these differences are important for understanding the nature of relations. Thus, in his Categories commentary Albert says:

Now the most general genus in the arrangement of this predicable is toward

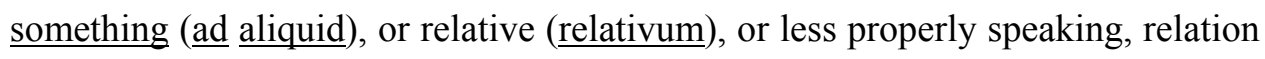
( $\underline{\text { relatio)}}$, as some people say. But it must be recognized that the most general genus is signified most clearly by the name 'toward something', which is a preposition together with 'something' in [the accusative] case. For this name conveys the two things that are in a relative, namely: [i] diversity, which the preposition indicates through its taking an object (transitionem), and [ii] the direction of the comparison, which the accusative case indicates when something is called 'toward something'. 41 
And Albert makes the same point in his commentary on the Metaphysics:

Now because this being [i.e., the being of a relation] always exists in that which looks-out toward something ( can, properly speaking, be designated in the way absolute things can. The genus of this being, therefore, is properly [called] relative (relativum); it is less properly called relation ( $\underline{\text { relatio)}}$ ) and it is called toward something ( $\underline{\text { ad }} \underline{\text { aliquid) }}$ most appropriately of all, since this [genus] has a mode [of being] which is opposed to that which is absolute. ${ }^{42}$

In these passages, Albert arranges the standard medieval terms for relation in decreasing order of appropriateness. In each case, moreover, his reason for preferring "toward something" seems to be that this term best expresses the nature of relations. As Albert says in the passage from his Categories commentary: "toward something" conveys the two things that are involved in the nature of relation, namely, diversity and direction. By "diversity" Albert appears to mean diversity of relata or things related. Relations always involve two (or more) things, whether the diversity between these things is real (as in the case of Simmias and Socrates), or merely conceptual (as in the case of Socrates and the teacher of Plato). When Albert speaks of "direction", moreover, he appears to be indicating that relations proceed, as it were, from one thing toward another. Albert sometimes puts these two points together by saying that relations have subjects of inherence whose relations they are and termini with respect to which they relate their subjects. $^{43}$

If the nature of relations is best expressed by the prepositional phrase "toward something", what about the other terms, "relative" and "relation"? At first glance, neither would seem to express the procession of relations from a subject to a terminus. The term "relative", however, masks an underlying complexity. In Latin, as in English, a thing 
cannot be merely relative; it must be relative to something. Hence, even if this term does not indicate the procession of relations on its surface, it does so at the level of deep logical structure. As for the term "relation", however, it would not appear to express this procession at all. According to Albert, what is expressed by this term is something midway between two things. ${ }^{44}$ This way of talking, however, is derived from the spatial metaphor of a road's being between two cities, which seems to lose the directionality of relation altogether. It is not surprising, therefore, that Albert says that this last term expresses the nature of relation least appropriately of all. Indeed, when he is being most careful, he uses "relation" exclusively to signify relational concepts. ${ }^{45}$

In these terminological remarks, Albert seems to me to be getting at what Bertrand Russell once called the "sense" of a relation. It is significant, I think, that when Russell speaks of this notion in the Principles of Mathematics, he comes very close to using Albert's terminology:

[I]t is characteristic of a relation of two terms that it proceeds, so to speak, from one to another. This is what may be called the sense of the relation, and is, as we shall find, the source of order and series. ${ }^{46}$

Again, a little further on he says:

We may distinguish the term from which the relation proceeds as the referent, and the term to which it proceeds as the relatum. The sense of a relation is a fundamental notion, which is not capable of definition. ${ }^{47}$

Russell discusses the notion of a sense at various places in his work, but the clearest accounts of it emerge in his discussions of the cognitive relation of judging. Consider, for example, the following passage from The Problems of Philosophy, where Russell also speaks of it as a "direction": 
It will be observed that the relation of judging has what is called a 'sense' or 'direction'. We may say, metaphorically, that it puts its objects in a certain order, which we may indicate by means of the order of the words in the sentence. (In an inflected language, the same thing will be indicated by inflections, e.g. by the difference between nominative and accusative.) Othello's judgment that Cassio loves Desdemona differs from his judgment that Desdemona loves Cassio, in spite of the fact that it consists of the same constituents, because the relation of judging places the constituents in a different order in the two cases. Similarly, if Cassio judges that Desdemona loves Othello, the constituents of the judgment are still the same, but their order is different. This property of having a 'sense' or 'direction' is one which the relation of judging shares with all other relations. The 'sense' of relations is the ultimate source of order and series $[\ldots]^{48}$

It is clear from these passages that Russell thinks of all relations, not just the cognitive relation of judging, as possessing a 'sense' or 'direction'. It is clear, moreover, that he thinks this sense or direction is an irreducible feature of relations, one which must be invoked to explain the structure and order we find in the world. Albert appears to be making a similar point when he says that relations are "toward something" or "relative" as opposed to merely standing 'between' things. But whereas Russell says that every relation has (or possesses) a sense, I suggest that we think of Albert as saying every relation is (or is identical to $)$ a sense. ${ }^{49}$

If something like this is right—and I don't want to push the analogy with Russell too far-then I think we can understand why Albert might be drawn to a form of what I am calling non-reductionism about relations. For if we think of relations solely in terms of ordinary monadic properties, as the reductive realists do, then we seem to lose the order or directionality in question. As Albert would put it, this directionality is an 
outward-looking feature of individuals, whereas ordinary monadic properties are wholly inward-looking.

To some extent, therefore, we can think of Albert as siding with Russell against the reductive realists, philosophers such as Abelard who want to reduce relations to nothing but ordinary monadic properties. Of course, we have to be careful here. Albert also rejects the existence of polyadic properties. Unlike Russell, therefore, he cannot think of directionality as a feature of polyadic properties. For him this directionality must be a feature of related individuals — or perhaps even better, a feature of ordinary monadic properties.

What Albert's theory appears to be calling our attention to, therefore, is a sort of middle road between reductive realism and the sort of realism defended by Russell. In order to make this clearer, let us return once more to our example involving Simmias and Socrates. According to the reductive realist, Simmias's being taller than Socrates is nothing but Simmias, Socrates, and the pair of heights instantiated by them. According to Russell, by contrast, there is in addition to these elements a polyadic property, being-

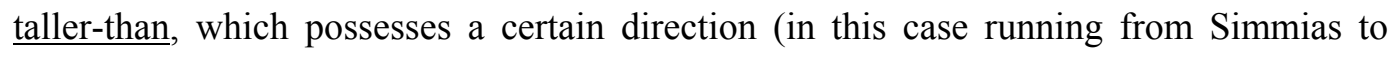
Socrates). Now, like the reductive realist, Albert rejects the existence of polyadic properties such as being-taller-than. Like Russell, on the other hand, he does not want to dispense with the feature of directionality. Evidently, therefore, we can think of Albert's view as something like Russell's view sans polyadic properties. Whereas Russell makes directionality a feature of relations, which just are for him polyadic properties, Albert identifies this directionality with relations (or cases of what he prefers to call toward

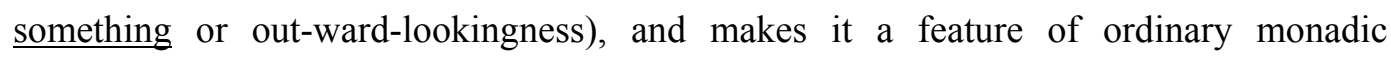
properties — or in this case, a feature of heights. 
The plausibility of this sort of theory will, of course, be challenged by proponents of both of the views that it purports to steer a middle course between. Reductionists such as Abelard, for example, will want to say that the ordinary monadic properties of individuals are all that's required to explain the relatedness in question, and hence that Albert's appeal to a special type of monadic property is gratuitous. (Moreover, in the case of quantitative relations, such as being-taller-than, Abelard's claim has a certain amount of plausibility. If this relation really supervenes on a pair of heights - that is, if it is really necessitated by them — then perhaps the heights themselves are sufficient to ground the applicability of the relational concept, 'is taller than.') On the other hand, however, non-reductionists such as Russell will criticize Albert's theory for misidentifying the nature of relations. If relations are really irreducible, they will say, then relations must be irreducibly polyadic.

It is not my purpose here to provide anything like a complete defense of Albert's theory. But I would like to indicate, at least, that Albert has the resources to respond to these objections. I begin with a few general remarks about the reductionist position.

According to a reductionist such as Abelard, Simmias's being taller than Socrates is nothing over and above a pair of ordinary monadic properties, say, Simmias's and Socrates's heights taken together-or perhaps just Simmias's height taken in certain circumstances. ${ }^{50}$ Now as we have seen, this type of reductive theory is often rejected on the basis of purely logical or semantic considerations: the fact that statements of the form " $\underline{x}$ is tall" are more perspicuously represented as of the form " $\underline{x}$ is taller than $y$ " is often thought to imply that "tallness" does not refer to a genuine monadic property (or even a pair of monadic properties) but is an elliptical way of referring to a polyadic property, being-taller-than. As we have seen, however, this type of objection rests on an unwarranted assumption. There is no reason, at least in principle, why an irreducibly 
polyadic predicate or concept cannot signify a monadic property (or pair of monadic properties).

But perhaps there is a way of reformulating this type of objection that is favorable to Albert's theory. For there is still a question as to why, if a view such as Abelard's is true, we would represent situations containing only monadic constituents as if they contained irreducibly polyadic ones. If Simmias's being taller than Socrates really is nothing ontologically over and above Simmias, Socrates, and their respective heights, then why, Albert might ask, do we represent the relation as if it were something over and above these things? At this point, Abelard can only appeal to our psychological makeup. We simply do represent (or at least are capable of representing) one and the same situation (say, Simmias's being six-feet-tall while Socrates is five-feet-ten) in these two very different ways.

Now even if one does not find such an appeal to psychology implausible, Albert's theory would seem to offer a better answer to the original question, namely, "Why do we represent Simmias's being taller than Socrates as distinct from Simmias's being six-feet-tall while Socrates is five-feet-ten?" According to Albert, the reason we represent these two situations (or states of affairs) as distinct is that they are distinct. Indeed, Albert might say, the logical incompleteness of predicates such as "is tall" or "is taller" calls our attention to precisely what makes these situations distinct-namely, the directionality involved in the one, but not the other situation.

Once this strategy for responding to reductionism has been identified, however, it is of course open to someone like Russell to deploy it against Albert's own theory. Indeed, we can imagine a Russellian asking: “Isn't it the presence of a genuinely polyadic property that best explains why we represent Simmias's being taller than Socrates as a situation of the form $\underline{x \mathrm{R} y}$ ?" The answer to this question, however, is not altogether clear. 
For one thing, the mere presence of a polyadic property is not sufficient to explain our representation of the situation. This is especially evident because being-taller-than is an asymmetrical relation; that is to say, if a statement of the form " $\underline{\mathrm{x}}$ is taller than $\underline{y}$ " is true, then a statement of the form " $y$ is taller than $\underline{x}$ " is false. What is required to explain our representation of this situation, therefore, is not merely the presence of a polyadic property but a polyadic property together with a certain sense or direction. But once we invoke the notion of a sense or direction, it is no longer clear that we need the polyadic property. For the mere presence of a sense or direction would seem to explain both (a) why we represent the situation as Simmias's being taller than Socrates, as opposed to the other way round, and (b) why we represent it more generally as of the form $\underline{x R y}$. After all, how else could we represent the fact that Simmias is directed toward Socrates?

Now, of course, Russell could try to insist that the sense or direction in question just is a polyadic property. Here again, however, it is not clear why his objection should have any force. For one thing, it is not clear that Russell can consistently maintain this position. According to him, all relations or polyadic properties have a sense. But if senses are themselves polyadic, then a potentially vicious infinite regress threatens: the sense of a relation will itself require a sense, and so on to infinity.

More to the point, however, it is not clear how anyone, much less Russell, could defend the claim that a sense or direction must be polyadic. Certainly there are situations that involve this directionality, and hence we can agree that it is a feature of the world that demands an explanation. But whether this feature must be construed as polyadic would appear to be as open to debate as the question, in the philosophy of mind, of whether intentionality is a many-place relation or a sui generis type of monadic property.

In the end, therefore, Albert's non-reductive realism would seem to provide a genuine alternative to the views standardly presented in the contemporary discussion of 
relations. Moreover, this alternative is not a mere logical possibility, but a position which ought to appeal to anyone who feels the weight of the purely logical or semantic considerations, but who also prefers the economy of an Aristotelian view of the world.

\section{ALBERT AND THE ARISTOTELIAN TRADITION}

In the course of discussing Albert's theory, I have introduced the elements of a framework for thinking about the main dialectical options that one might take with respect to the nature and ontological status of relations. Before closing, I want to assemble that framework and then briefly indicate how Albert's discussion sheds light on the development of medieval-Aristotelian theories generally.

As we have seen, Albert begins his discussion with a characterization of relations as the significata of relational predicates. By now we are in a position to appreciate the advantages of this starting point: it leaves all of the important ontological questions open. Thus, Albert's characterization neither begs the question in favor of realism or antirealism (though his own substantive views in semantics lead him to say that conceptualism is the only possible form of anti-realism); nor does it beg the question, among realists, in favor of polyadic properties; nor does it even beg the question, among realists without polyadic properties, in favor of reductionism. Indeed, if we ignore Albert's own substantive views in semantics, I think we can see that his characterization of relations enables us to construct a helpful taxonomy of the main types of theories of relations. ${ }^{51}$

Assuming relational predicates are significant, we can define Realism as the view that relations are (non-linguistic) extramental beings, and Anti-Realism as the denial of this view. Of course, these definitions leave open the possibility of distinguishing various forms of both Realism and Anti-Realism. Assuming that Anti-Realism is true, 
relations must either be mere words (whether spoken or written), mere concepts, or some combination of words and concepts. The first two views are forms of what we might call "Pure Anti-Realism"- that is, "Pure Nominalism" and "Pure Conceptualism" respectively. It is difficult to identify anyone who has actually held the view that I am calling Pure Nominalism, but perhaps Willfrid Sellars is an example from the last century. ${ }^{52}$ As for Pure Conceptualism, we have seen that Albert thinks it is traceable to Avicenna and Alfarabi, although at least in the case of Avicenna it seems clear to me that he does not endorse the view. ${ }^{53}$ There are, however, other Islamic thinkers who appear to have endorsed a form of Pure Conceptualism, including the members of a group of orthodox Muslim theologians known as the Mutakallimūn. ${ }^{54}$ Again, Peter Aureoli (d. 1322 ) is a representative of Pure Conceptualism in the Latin West. ${ }^{55}$ As for the view we might call "Impure Anti-Realism", the view that relations are both words and concepts, I have not been able to identify any genuine representatives. William Ockham certainly speaks in ways that are suggestive of this form of anti-realism, but in the end it cannot be said to represent his own position. ${ }^{56}$

As in the case of Anti-Realism, we can distinguish several species of Realism. The most important division among realists - namely, those who think of relations as (non-linguistic) extramental beings - is the division between those who identify relations with polyadic properties and those who do not. The first species of Realism would include many (if not most) contemporary, analytic philosophers, whereas the second would include almost everyone writing prior to the twentieth century. As we have seen, moreover, there is an important division among realists without polyadic properties. Some, such as Peter Abelard, attempt to reduce relations to ordinary monadic properties, whereas others, such as Albert the Great, deny that such a reduction can be achieved (and hence identify relations as a sui generis type of monadic property). 
Now, on the basis of this taxonomy, we can begin to understand why particular philosophers working within the Aristotelian tradition have preferred one sort of theory over another. As we have seen in the case of Albert, the position these philosophers take on the long-standing controversy surrounding the Aristotelian categories (namely, whether these categories classify words, concepts, or things) in large part determines their preference for realism about relations, or some form of anti-realism (such as nominalism or conceptualism). Again, the extent to which they are influenced by Aristotle's conception of relation as a specific type of accident is important for determining their attitude towards polyadic properties. During the ancient and early medieval periods, philosophers habitually rejected the existence of real polyadic properties. In the later medieval and early modern periods, however, as philosophers felt freer to resist Aristotle's conception of accident, they began gravitating toward a view more hospitable to such properties. ${ }^{57}$ Finally, among those Aristotelians who reject the extramental existence of polyadic properties, the division between reductionists and non-reductionists in large part hinges on the question whether the categories in general, or the category of relation in particular, should be conceived of as irreducible.

As we have seen, Albert himself occupies an interesting place on this taxonomy, since he accepts the view that relations comprise an irreducible, accidental category of extramental being (the view that I have been calling non-reductive realism). It is difficult to say how widespread this form of realism was during the Middle Ages, but shortly after Albert's death it became the focus of an intense philosophical debate. Indeed, the question whether relations are identical to their foundations was among the most hotly disputed and intractable questions of later medieval philosophy. Although this sort of question is not taken very seriously today, Albert's discussion helps us to see why not only the question, but his specific answer to it are of more than historical interest. What 
is required of any theory of relations is that it account for the data of relational situations, which is precisely what Albert intends his theory to do. Now admittedly some of Albert's contemporaries are going to prefer a form reductive realism, on the grounds of ontological parsimony, just as some of our own contemporaries are going to prefer a form of realism with polyadic properties, perhaps on the grounds of its explanatory elegance or simplicity. By introducing relations as a sui generis type of monadic property, however, Albert may have hit upon a way of combining the theoretical advantages associated with both types of theory, namely, ontological parsimony and explanatory simplicity. ${ }^{58}$ 
APPENDIX

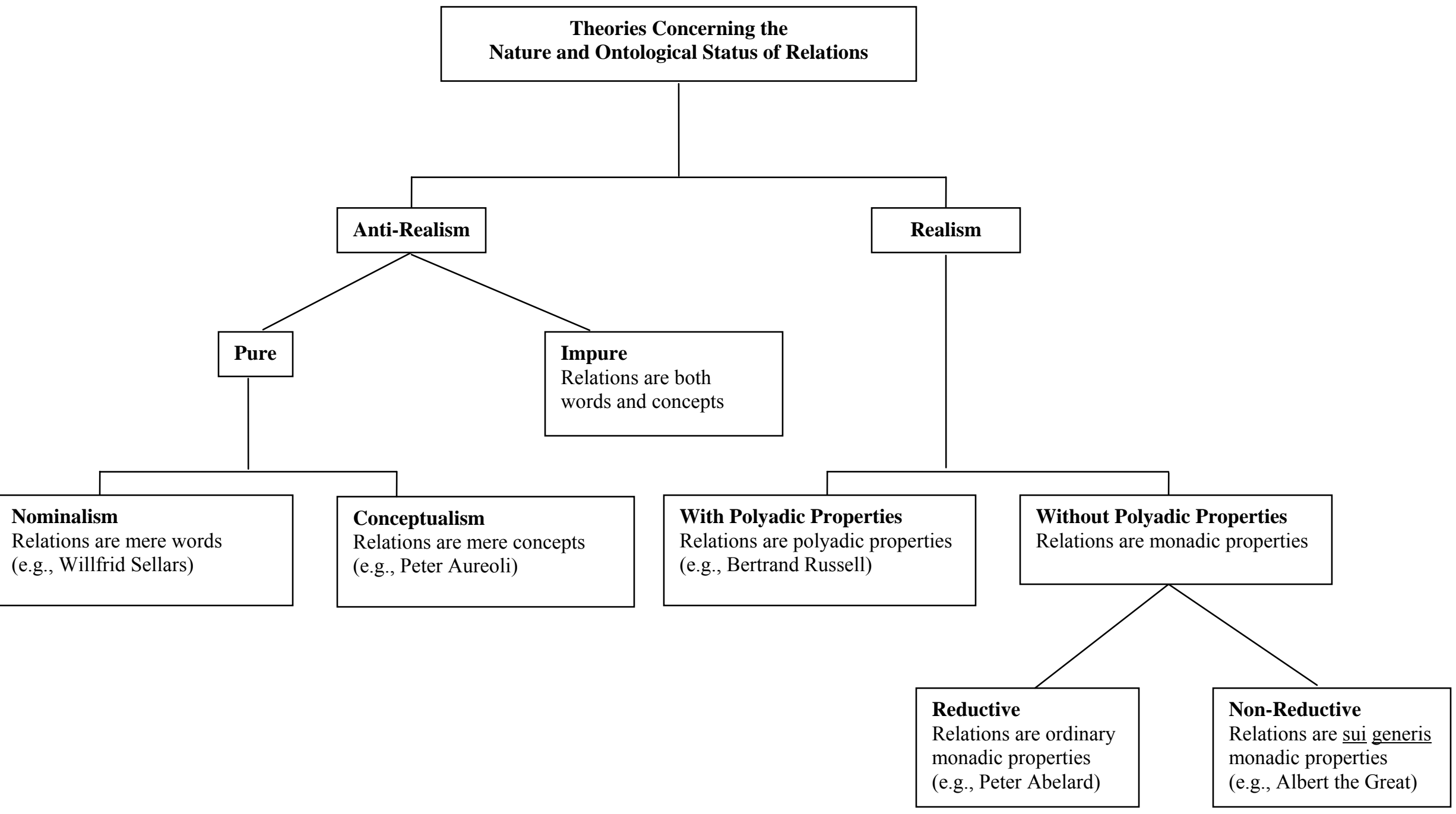




\section{NOTES}

${ }^{1}$ In this paper I ignore complications that arise in connection with reflexive relations such as identity.

${ }^{2}$ For a brief survey of Albert's life, works, and historical significance see Alain de Libera, “Albert the Great", in The Routledge Encyclopedia of Philosophy, ed. Edward Craig (London: Routledge, 1998); and James A. Weisheipl, "Life and Works of St. Albert the Great", in Albertus Magnus and the Sciences: Commemorative Essays 1980, ed. James A. Weisheipl (Toronto: Pontifical Institute of Mediaeval Studies, 1980), 13-51. For a more extensive discussion, see Alain de Libera, Albert le Grand et la Philosophie (Paris: Vrin, 1990), which has come to be regarded as the standard work of reference on Albert's philosophy.

${ }^{3}$ In the contexts on which I shall be focusing, Albert speaks as if every relational predicate introduces a special type of monadic property, one which exists in extramental reality. As we shall see, however, all that he is strictly committed to saying here is that at least some relational predicates introduce such properties. In other contexts, therefore, he is free to maintain that, while some relational predicates introduce sui generis monadic properties, yet others introduce ordinary monadic properties, or just individuals, or nothing in extramental reality at all. For a discussion of the sorts of considerations that preoccupy Albert in all of his discussions of relations, see Crescentino Marinozzi, "La realtà delle relazioni secondo S. Alberto Magno" in Laurentianum 6 (1965), 31-72. For an analysis of the distinction between real (or extramental) vs. merely conceptual relations in one of Albert's early theological works, see Scott MacDonald, "The Metaphysics of Goodness and the Doctrine of Transcendentals" in Being and Goodness: The Concept of the Good in Metaphysics and Philosophical Theology, ed. Scott MacDonald (Ithaca: Cornell University Press, 1991), 31-55, esp. 42f. Finally, for a discussion of Albert's views on the so-called transcendental relations, see Crescentino Marinozzi, "La relazione trascendentale in S. Alberto M." in Laurentianum 5 (1964), 71-113.

${ }^{4}$ A critical edition of Albert's works has been underway since 1951, Alberti Magni Opera omnia

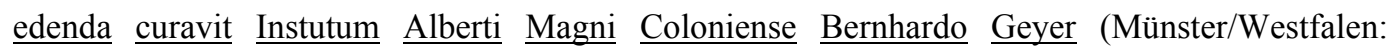


Aschendorff). Albert's commentary on the Metaphysics (hereafter referred to as "In Metaph.") appears in vol. 16 as Metaphysica, ed. Bernhard Geyer (1960-1964); the material that I shall be discussing occurs in pt. 1, bk. 5, tr. 3, 266a-271b. A critical edition of Albert's commentary on the Categories (hereafter referred to as "De praedic.") has not yet appeared, so I cite the most recent printed edition in which it occurs, Alberti Magni Opera omnia, ed. Auguste and Émile Borgnet, 38 vols. (Paris: Vivès, 1890-1899). The commentary on the Categories appears in vol. 1 as Liber de praedicamentis, ed. Auguste Borgnet (1890); the material that I shall be discussing occurs in tr. 4, 222a-242b.

I should indicate at the outset that, although a decade or more separates the writing of Albert's Categories and Metaphysics commentaries, these two works do not seem to me to contain any substantive doctrinal differences with respect to the points I consider. For a discussion of the dating of Albert's works, see the references cited in note 2.

\section{${ }^{5}$ Categories $1 \mathrm{a} 25$.}

${ }^{6}$ Boethius sets the precedent here. In his commentary on the Categories, which introduced medieval philosophers to all three terms, he not only alternates among them but explicitly denies that there is any difference in meaning between two of them, namely, "toward something" and "relative": "Sive autem relativa dicamus, sive ad aliquid, nihil interest." See Boethius, In

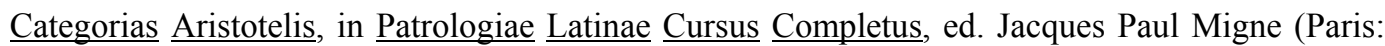
Vivès, 1860), vol. 64, 217a.

${ }^{7}$ Medieval philosophers use the same terms to refer to predicates and the entities signified by them.

${ }^{8}$ The medieval distinction between absolute and relative terms corresponds, therefore, to the contemporary distinction between monadic and polyadic predicates. It must not be inferred from this, however, that what medieval philosophers call "absolute" and "relative forms" corresponds to what we call "monadic" and "polyadic properties" (respectively). An absolute form is just an entity that is signified by an absolute term, and a relative form (or relation) is an entity signified by a relative term. Since one and the same entity can, however, be signified by both types of 
terms, it is possible for one and the same thing to be both absolute and relative (though, of course, nothing could be both monadic and polyadic). Indeed, thE possibility of a relative form's being absolute was exploited by number of philosophers during the Middle Ages, namely, all those who claimed that relations are identical with their absolute foundations. I discuss the view of one such philosopher in "Abelard's Theory of Relations: Reductionism and the Aristotelian Tradition", The Review of Metaphysics (1998) 51: 605-631. Cf. also Mark G. Henninger, Relations: Medieval Theories 1250-1325 (Oxford: Clarendon Press, 1989).

${ }^{9}$ In the end, Albert thinks that this characterization of relations won't quite do. Like other medieval philosophers, he thinks that it provides a necessary, but not a sufficient condition for being a relation, and so requires further refinement. We can ignore these complications here, but for further discussion see my "Medieval Theories of Relations before Aquinas: Categories Commentaries, 510-1250 A.D.”, 2 vols. (Ph.D. diss., University of Iowa, 1996), vol. 1, chaps. 2 and 5.

${ }^{10}$ This view is, of course, common among medieval philosophers, who trace it back to Aristotle's

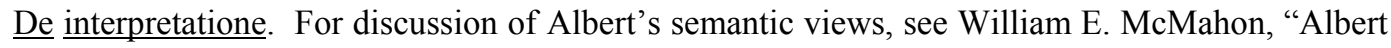
the Great on the Semantics of the Categories of Substance, Quantity, and Quality", in Historiographia Linguistica, VII (1980), 145-57. For further discussion and references, see E. J. Ashworth, "Signification and Modes of Signifying in Thirteenth-Century Logic: A Preface to Aquinas on Analogy", in Medieval Philosophy and Theology 1 (1991), 39-67; and Gyula Klima, “The Semantic Principles Underlying St. Thomas Aquinas's Metaphysics of Being”, in Medieval Philosophy and Theology 5 (1996), 87-141.

${ }^{11}$ Although this characterization of realism and conceptualism is the one suggested by Albert's discussion, and is acceptable for our purposes here, in other contexts it would have to be refined. For medievals such as Albert often distinguish among at least three different types of concepts, depending on their relationship to their objects, namely: (1) concepts such as 'man' or 'horse' that have something immediately corresponding to them in extramental reality (namely, individual human beings or horses); (2) concepts such as 'species' or 'genus' that have something 
corresponding to them in extramental reality, but only mediately (thus, 'species' immediately represents other concepts, such as 'man' and 'horse', which in turn immediately represent extramental realities); and (3) concepts, such as 'chimera' or 'unicorn', that have nothing in extramental reality corresponding to them, either mediately or immediately. On the basis of this distinction, however, we can see that there are actually three different positions one can take with respect to relations (which I shall refer to, respectively, as Realism, Moderate Conceptualism, and Radical Conceptualism):

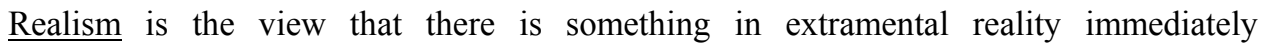
corresponding to at least some of our relational concepts.

Moderate Conceptualism is the view that there is something in extramental reality corresponding to our relational concepts, but only mediately.

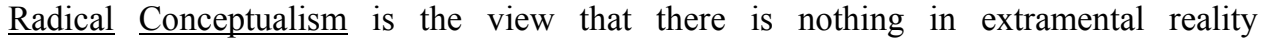
corresponding to our relational concepts, either mediately or immediately.

As we shall see, the only form of conceptualism that Albert is concerned with is a form of moderate conceptualism, according to which relational concepts are at least indirectly or mediately grounded in the objective properties of things.

${ }^{12}$ “Ex his et similibus rationibus moti fuerunt Antiqui et fere omnes praeter Platonem et Aristotelem [...] Nos autem Platoni et Aristoteli consentientes, dicimus ad aliquid esse generalissimum, et esse unum de primis generibus accidentis [...]" (De praedic., 223a).

${ }^{13}$ "Nos autem dicimus ad hoc, quod in veritate secundum Peripateticorum sapientiam relatio habet esse, sed non habet esse nisi in relativo, quod est ad aliquid" (In Metaph., 266b).

${ }^{14}$ Avicenna, for example, whom Albert frequently cites, endorses this conception of accidents explicitly, as does Albert's most famous student, Thomas Aquinas. (Compare Avicenna, Liber $\underline{\text { de }}$ 


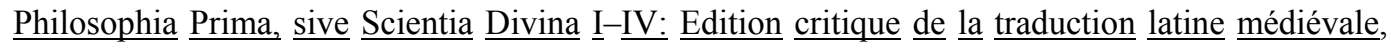
ed. S. Van Riet [Louvain and Leiden, 1977], 173; Thomas Aquinas, $\underline{\text { Scriptum super libros }}$ Sententiarum, ed. Pierre Mandonnet [Paris: Léthielleux, 1929], I, d. 27, a. 1, ad 2.) For Albert's endorsement of this conception of accidents see De praedic., $241 \mathrm{~b}$ ad 1.

${ }^{15}$ In a medieval context, discussions of fatherhood and sonship almost always suggest the relations in the Trinity. It may be that Albert has the divine relations in mind here as well.

16، Item videtur quod filiatio et paternitas non differant nisi penes terminos, sicut via quae est a Thebis ad Athenas, et ab Athenis ad Thebas, quae eadem est, quamvis terminis differat" (De praedic., 241a). The example involving the road which runs from Thebes to Athens is a traditional one, and often comes up in medieval discussions of relations. Aristotle uses this example when he discusses motion in the Physics (see 202b11-15), but it may trace back even further to Heraclitus's claim that "the road up and the road down are one and the same".

17،"Et quod objicitur de eadem via quae est de Thebis ad Athenas, et e converso, dicendum quod omnino simile non est, nisi in terminis: medium autem extensum non habet” (De praedic., 241b). ${ }^{18}$ Albert does not explicitly say which Zeno he has in mind, but presumably it is Zeno of Citium (334-262 BC), the founder of the Stoic school. This seems likely because the Stoics - at least as transmitted to the Latin West and interpreted by Sextus Empiricus, Plotinus, and Simpliciuswere generally taken to reject any form of realism about relations. See Mark G. Henninger, Relations: Medieval Theories 1250-1325 (Oxford: Clarendon Press, 1989), 9 and the texts cited in his notes. Cf. also Julius R. Weinberg, Abstraction, Relation, and Induction (Madison: University of Wisconsin Press, 1965), 79-81.

19“"Adhuc autem fortius objecerunt quidam posteriorum, sicut Avicenna et Alfarabius, dicentes quod nulla forma quae sit ens, est in re quae non sit absoluta secundum esse quod habet in ipsa, sicut patet inducendo de calido, frigido, albo, et nigro, et omnibus aliis: sed comparatio quae fit rerum ad invicem secundum formas quae sunt in rebus, fit actu rationis, quae dicit quod in quibus non est una qualitas sunt dissimilia, et in quibus est una sunt similia: comparationis ergo forma 
quae est in his quae sunt ad aliquid, non est res sed ratio, ut videtur, quia nihil est extra animam comparantis unum alteri” (De praedic., 222b-223a).

${ }^{20}$ Nor can we merely check the relevant texts of Avicenna or Alfarabi, since it is unclear what texts of theirs (if any) Albert is relying upon here. Albert does not give us any specific references. Moreover, the texts of Avicenna and Alfarabi that he relied upon for his commentaries or paraphrases on the Organon are for the most part lost today.

${ }^{21}$ For Avicenna's view, see the discussion of relations in Philosophia Prima, tr. 3, chap. 10, $173-$ 83. For some doubts about my realist interpretation of this discussion, as well as some interesting suggestions about Alfarbi's own view and its relation to Avicenna's, see M. E. Marmura, “Avicenna's Chapter, 'On the Relative', in the Metaphysics of the Shifâ” in Essays on Islamic Philosophy and Science, ed. G. F. Hourani (Albany: State University of New York Press, 1975), 83-99. Cf. also Julius R. Weinberg, Abstraction, Relation, and Induction: Three Essays $\underline{\text { in the }}$ History of Thought (University of Wisconsin Press, 1965), 1-119, esp. 91f. 22، “A $]$ d aliquid autem non est ens ratum apud naturam extra, sed ens rationis" (De praedic., 223a).

${ }^{23}$ Thus, in treating the very first anti-realist objection, Albert simply adopts his objectors' terminology, according to which "being toward something [or related] just consists in being

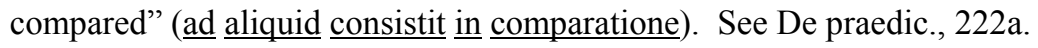

${ }^{24}$ Albert's willingness to speak in this way may be explained in part by the fact that, although the term comparatio has psychological overtones in Latin, its original meaning is more objective than the English transliteration would suggest. The Latin infinitive comparare means to bring together or unite. Literally, therefore, a comparison is just that by virtue of which two or more things are united. For a helpful discussion of comparatio and various other terms used by medieval philosophers to signify relations, see Robert W. Schmidt, The Domain of Logic $\underline{\text { According to }}$ Saint Thomas Aquinas (The Hague: Martinus Nijhoff, 1986), 133. 
${ }^{25}$ For further discussion of this type of objection, see Panayot Butchvarov, Being qua Being: $\underline{\text { A }}$ Theory of Identity, Existence, and Predication (Bloomington: Indiana University Press, 1979), $241 \mathrm{f}$.

${ }^{26}$ It is worth emphasizing here that, although the objectors accept the conclusion at (4), they do not appear to think that relational judgments depend for their truth solely on the activity of the mind. For as they say, it is only things "having a single quality" which reason judges to be similar, and only things "lacking a single quality" which it judges to be dissimilar. And these claims are just particular instances of their more general principle that relational judgements or comparisons come about "in accordance with forms that are in the things [compared]". Evidently, therefore, the objectors believe that whenever two or more things are related, their being related depends at least partly on the objective properties exemplified by them. Cf. note 11 above.

${ }^{27}$ “'Ad hoc autem quod posterius objiciunt, dicendum videtur quod per comparationem dupliciter est considerare, secundum aptitudinem scilicet et secundum actum. Secundum aptitudinem quidem est in rebus [...] Secundum actum autem comparatio est in ratione vel anima comparantis: et actus ille non facit, quod non secundum aptitudinem sit in rebus comparatis: et ideo secundum aptitudinem quidem est in rebus, secundum perfectionem autem est in ratione" (De praedic., 224a-224b).

${ }^{28}$ Locke actually divides the latter sort of qualities (namely, those that do not resemble the ideas which they produce) into two categories, depending on whether they produce their ideas directly or indirectly. Strictly speaking, therefore, he thinks that we must distinguish not only between primary and secondary qualities, but also between both of these and 'a third sort,' which for lack of a better name are typically called tertiary qualities.

${ }^{29}$ John Locke, An Essay Concerning Human Understanding (Oxford: Oxford University Press, 1975) bk. ii, chap. 7, sect. 15.

${ }^{30}$ In a medieval context, forms of the Latin term praedicabilis typically refer to the five predicables discussed in Porphyry's Isagoge. In his Categories commentary, however, Albert often uses praedicabilis in its more generic or literal sense to mean that which can be predicated. In this 
context, therefore, a modum praedicabilium is just a way that something can be predicated, or as I have rendered it, "a mode of predication".

31،"Et hoc multos decipit in isto praedicamento: et est quod dicit Aristoteles quod quaedam insunt ut accidens, quaedam autem ut quodammodo se habere ad alterum. Et bene concedendum est quod accidens istud minus habet de ente quam aliud quod est absolutum: sed ex hoc non sequitur quod nihil habeat, et secundum quod habet de ente accidentali non ponat modum praedicabilium ab aliis praedicabilibus accidentis distinctum et separatum" (De praedic., 224b).

${ }^{32}$ Principles of Mathematics (Cambridge, England: Cambridge University Press, 1903), sects. 212-14.

${ }^{33}$ Julius R. Weinberg, Abstraction, Relation, and Induction (Madison: University of Wisconsin Press, 1965), 63, n. 3; Reinhardt Grossmann, The Categorial $\underline{\text { Structure of the World }}$ (Bloomington: Indiana University Press, 1983), 161f. Fred Wilson combines both sorts of consideration, meaning and logical form, in "Weinberg's Refutation of Nominalism", Dialogue 8 (1969), 466-72.

${ }^{34}$ See my "Abelard's Theory of Relations: Reductionism and the Aristotelian Tradition", The Review of Metaphysics (1998) 51: 605-631.

${ }^{35}$ I call this form of realism "reductive" solely for the purpose of indicating that the properties grounding the applicability of relational concepts are identified by it with ordinary monadic properties, and not the members of some sui generis type of monadic property.

${ }^{36}$ The difference between these two alternatives is purely semantic. On the former sort of view, a relational predicate such as "is taller than" will signify a pair of heights collectively, whereas on the latter, it will signify a single height in certain circumstances. In "Abelard's Theory of Relations: Reductionism and the Aristotelian Tradition" (The Review of Metaphysics [1998] 51: 605-631.), I attributed the former sort of view to Abelard, whereas I now think that it is more likely that he held the latter (or at least alternated between the two). For further discussion of the differences between these two sorts of view and the broader historical and semantic issues 
surrounding them, see Gyula Klima, "Ontological Alternatives vs. Alternative Semantics in

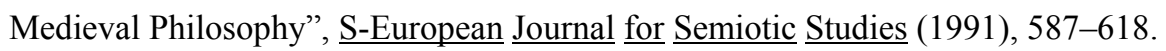

37،Difficile est nobis loqui de ad aliquid et relatione, quoniam aliam penitus habet naturam et esse a generibus entis, quae sunt determinata" (In Metaph., 266a).

38، [...] alium ab inductis generibus habet modum entitatis, quia alia genera dicunt ens absolutum, et ideo essentiae eorum sunt constantes ex suis principiis absque principiis subjecti, in quo sunt, sicut quantitas et qualitas. Istud autem non habet entitatem aliquam talem, sed ipse subjecti respectus est sibi entitas" (In Metaph., 266b).

${ }^{39}$ This translation of respectus is admittedly somewhat awkward, but it serves to bring out the precise visual metaphor implied by Albert's use of this expression. As Albert is using the term, a

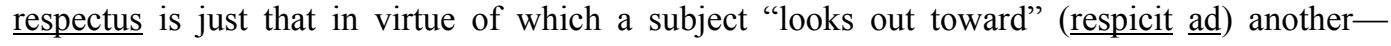
namely, its outward-looking-ness. The significance of this visual metaphor will become apparent in section 6, where I argue that it helps to explain why Albert refuses to reduce relations to ordinary monadic properties.

${ }^{40}$ See, e.g., In Metaph., 267.

41، Generalissimum autem in huius praedicabilis coordinatione est ad aliquid, vel relativum, vel minus proprie, ut dicunt quidam, relatio: sed notandum quod nullo nomine ita expresse significatur generalissimum sicut per hoc quod est ad aliquid, quod est praepositio cum casuali: hoc enim duo importat quae sunt in relativo, diversitatem scilicet per transitionem quam notat praepositio, et terminationem comparationis quam notat casus accusativus, cum dicitur ad aliquid" (De praedic., 225b).

42،“[...] et quod hoc esse semper est in eo quod respicit ad aliquid, et non est essentia quaedam absolute designabilis proprie loquendo. Et ideo genus huius entis proprie relativum est, et minus proprie relatio vocatur et convenientissime vocatur ad aliquid, quia hoc oppositum modum habet ad absolutum” (In Metaph., 267a).

${ }^{43} \mathrm{Cf}$. De praedic., $241 \mathrm{~b}$ ad 1.

${ }^{44}$ Cf. In Metaph., 266 b. 
${ }^{45}$ De praedic., 226a-226b; In Metaph., 266b. It is usually thought that there was no term in ancient Greek corresponding to the abstract word "relation". (See, e. g., J. L. Ackrill, Aristotle's

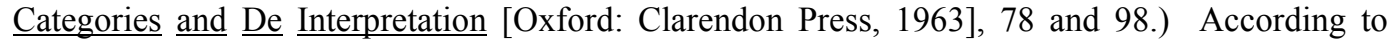
Albert, however, Plato invented the term "toward something" for the sake of avoiding the misleading connotations of "relation" and "relative", both of which he suggests were in common use at the time. Albert appeals here to the authority of Porphyry and Alexander, but unfortunately he does not refer to any specific texts. See De praedic., 226a.

${ }^{46}$ The Principles of Mathematics, (London: Allen \& Unwin, 1937), sect. 94.

${ }^{47}$ Ibid.

${ }^{48}$ The Problems of Philosophy (Indianapolis: Hackett Publishing Company,1984), 126-7.

${ }^{49}$ Strictly speaking, this suggestion needs to be qualified so as to apply only to those relations that are sui generis monadic properties. Cf. note 3 above.

${ }^{50}$ See note 36 above.

${ }^{51}$ See the accompanying diagram in the appendix.

${ }^{52}$ According to Sellars, all talk about properties, whether monadic or polyadic, is metalinguisticthat is, a disguised way of talking about linguistic expressions. See Willfrid Sellars, "Abstract Entities", Review of Metaphysics (1963), 627-71.

${ }^{53}$ Strictly speaking, what I am here calling "Pure Conceptualism" should be called "Pure $\underline{\text { Moderate }}$ Conceptualism" and distinguished from "Pure Radical Conceptualism". See note 11 above. However, since no medieval philosopher I know of ever endorsed Radical Conceptualism, I do not take account of it in my taxonomy.

${ }^{54}$ Julius R. Weinberg, $\underline{\text { Abstraction, }} \underline{\text { Relation, }}$ and Induction (Madison: University of Wisconsin Press, 1965), 89-93.

${ }^{55}$ See Mark G. Henninger, Relations: Medieval Theories $\underline{1250-1325}$ (Oxford: Clarendon Press, 1989), 150-73.

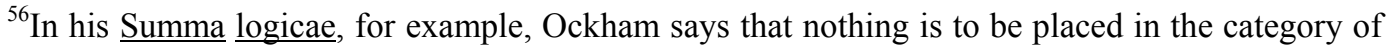

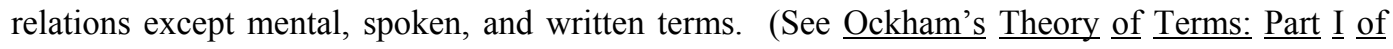




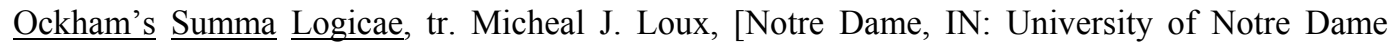
Press, 1974], 158-77, esp. 171.) Although this certainly suggests a form of Impure Realism, it is clear from the text that when Ockham speaks of what is 'placed in the category (or genus) of relation' he is not speaking of the significata of all relational predicates, but only of the signficata of the term "relation" (and the other names for this category, namely, "relative" and "toward something"). Thus, although it is true that he thinks some relational predicates (namely, "relation", "relative", and "toward something") signify merely mental, spoken, and written terms, he nonetheless thinks that most others (such as "taller", "similar", etc.) signify things in extramental reality. For a discussion of Ockham's theory of relations, and some of its nuances, see See Mark G. Henninger, Relations: Medieval Theories 1250-1325 (Oxford: Clarendon Press, 1989), 119-49.

${ }^{57}$ See Mark G. Henninger, Relations: Medieval Theories $\underline{1250-1325}$ (Oxford: Clarendon Press, 1989), esp. 174-86.

${ }^{58} \mathrm{I}$ presented earlier versions of this paper at Calvin College, Cornell University, Loyola University of Chicago, and Purdue University. I am grateful to audiences on these occasions for useful comments and discussion. I am also grateful to Susan Brower-Toland, Gyula Klima, Paul Studtmann, Micheal Rea, two anonymous referees at Archiv, and especially Scott MacDonald for detailed written comments and suggestions. 